\title{
The Follow UpVillage Examination Report (Case StudyOn Villagein Western Sumbawa)
}

\author{
Hapid, Titiek Herwanti, Hamdani Husnan \\ Mataram University \\ Pogram Magister Akuntansi Pascasarjana Universitas Mataram 2017
}

\begin{abstract}
This study aimed to analyze the inspection reports Village in West Sumbawa qualitative method with case study approach. The phenomenon of this study are based on the results of annual monitoring by the monitoring unit of West Sumbawa District Inspectorate underlining the fact that the completion of the follow-up is still in progress and has not been acted upon. The study found a lack of good communication at the management level of the work unit Village in West Sumbawa regency and still lacks the human resources that have educational competence equivalent to its responsibilities, so that the completion of the follow-up by the work unit Village is not achieved with the maximum and the follow-up is still not followed up by the Village. For repairs to the front, in general, work units Villagers led by the Village head must have the commitment and the efforts of the completion of the follow-up so that they can communicate better and work units, especially the head of the Village with financial managers Village should involve all components within the organization to establish a pattern of relationships in the settlement of the follow-up tasks.
\end{abstract}

Keywords: auditing, examination, follow-up, monitoring, supervision.

\section{Introduction}

The GOI Internal Audit Standards prepared by the Indonesian Government Auditor Association (AAIPI, 2013: 01) state that bureaucracy reform aims to create a professional government bureaucracy with adaptive, integrity, high performance, clean, corruption-free, collusion and nepotism characteristics. Able to serve the public, neutral, prosperous, dedicated, and uphold the basic values and codes of conduct of the state apparatus. To achieve the objectives of bureaucratic reform, the effective role of the Government Internal Supervisor is required, namely in the form of: (a) Providing adequate confidence in the obedience, efficiency, and effectiveness of achievement of task and functions of government agencies (assurance activities) ; (b) provide early warning and improve the effectiveness of risk management in the implementation of duties and functions of government agencies (anti corruption activities); And (c) provide inputs that can maintain and improve the quality of governance of the tasks and functions of government agencies (consulting activities).

The Government, through the Ministry of Administrative Reform, has assigned the Functional Position of the Regional Governmental Supervisory Officer and the Functional Position of the Auditor having scope, duties, responsibilities and authority to conduct internal supervision on government agencies, Or other parties in which there is a state interest in accordance with the laws and regulations. Thus, there are two functional positions that perform internal supervision on government agencies in the region, both at the provincial government and district / city government. The positions of these two positions are the same as the internal functional technical supervisors under the Government Internal Supervisory Apparatur, in this case the Inspectorate (Prabowo, 2014).Policies West Sumbawa Regency Government oversight is one form and determination to support the ideals of reform to realize a clean governance and authoritative as a consequence of creating districts that civilized nature. The policy was taken by the management (agency or official who has the authority to take decisions in the field of supervision) and serve as a guideline for all members of the organization in carrying out APIPs supervisory duties.(Inspektorat KSB, 2015),

West Sumbawa District Inspectorate as Government Internal Supervisory Apparatur has the role and function of government affairs monitoring duties set out in Article 4 PERMENDAGRI No. 64/2007. Inspectorate provincial, district / city has a function as surveillance program planning; policy formulation and monitoring facilities; inspection, investigation, testing and assessment of supervision. 
Auditor is executive oversight has a fundamental duty to implement internal controls on government agencies and make recommendations based on the findings of the examination are presented in the report of inspection results. The benefits of internal controls through audit procedures are not just a number of the findings reported, but also in the form of effective follow-up by the auditee. Internal controls will be useless without the corrective actions in the completion of the follow-up so that the objectives of supervision are not achieved improved performance for the organization and will cause public distrust.(Hasmawali, 2012),

Follow-up inspection resultswithin the scope of local government in Indonesia has been regulated in the Republic of Indonesia Regulation No. 79/2005 on Guidelines for Development and Control of Local Government, PERMENDARI No. 23/2007 on Guidelines for Supervision of the Implementation Procedures for Local Government and PERMERNPAN No. 9/2009 on General Guidelines for the Implementation, Monitoring, Evaluation and Reporting Follow-up Results of Functional Supervision. Demands adherence to the completion of the follow-up results of the auditor or APIPs in Indonesia in the aforementioned regulation, legally imply an obligation to its completion.

This study aims to determine how the completion of follow-up was done by Village in West Sumbawa regency. Their follow-up have not been and / or are not followed up triggers urgency in the completion of follow-up. As long unfinished recommendations are acted upon, it will display a new recommendation on the results of the next examination that the auditor will accumulate recommendation which will certainly affect the performance assessment of officials Village. Against the completion of follow-up of non-compliance by Village who did not respond to several stages of alert, the completion of the administrative follow-up findings will be reported to the leadership APIP and for financial findings will be conveyed to

(MP -TGR). Based on that need for heightened awareness of Village to quickly finish APIP findings that the problem is not protracted and avoid sanctions in accordance with applicable regulations. so as to realize a clean and respectable government.

Research on completion TLHP have pretty much done by researchers before them have done Prihartono (2009), which examines the implementation of functional supervision in order to aim to optimize the performance of the Inspectorate General of the Ministry of Agriculture, Hasanah (2012), which examines the phenomenological study on the Quality Audit Officers Regional Inspectorate (Study on Inspectorate NTB), Arini (2014) which analyzes the role of management in the follow-up examination report by the working unit internal audit at Sanglah Hospital in Denpasar, in 2012, Hasymi (2016), which examines the follow-up evaluation findings of the internal audit as an element of optimizing the financial management and Suryanto (2016) who studied the delay in the follow-up study findings Inspectorate inspection area Kulon Progo Regency Yogyakarta and managerial implementation.

Referring to the description of previous studies may be explained that the completion TLHP studied based on the perspective of the perpetrators in Village which are based on PERMENPAN No. 9/2009. In the context of supervision, the auditee should promote adherence to follow the procedures, standards, and rules in solving the followup as recommended by the auditor to obtain reasonable assurance of the effectiveness and efficiency of the organization.

Implementation of the completion of the follow-up by the auditee is a form of success in the process of policy implementation. Implementsi success criteria of policies by Edward III, 1984 in(Akib, 2010) there are four (4) factors namely, communication, resources, bureaucratic attitude or executive and organizational structure, including work flow bureaucratic procedures.

Completion TLHP by the West Sumbawa Regency Village be monitored in accordance with the mandate PERMENPAN No. 9/2009. The monitoring carried out by the monitoring unit Inspectorate West Sumbawa regency, namely sub-section evaluation and reporting as a responsible administration TLHP settlement. Annual Monitoring Reports (LHPT) compiled by grouping the findings of the auditor LHP three (3) types of findings, namely: the occurrence of the loss to the state / region, the findings of the tax / levy has not been paid and the findings of the administrative problems. The findings present a kind of four (4) status of completion of the follow-up implemented by Village that status has been completed, in progress, the status of pending and status can not be acted upon.

TLHP completion status conditions by Village and Village in West Sumbawa regency in the recapitulation LHPT for the period from January 2016 are presented in Table 1, as follows:

Table 1: Recapitulation report the results of the monitoring of the follow-up by the monitoring unit of of the Inspectorate of West Sumbawa Regency

\begin{tabular}{|c|c|c|c|c|c|c|c|}
\hline \multirow{2}{*}{$\begin{array}{c}\text { findings } \\
\text { code }\end{array}$} & \multirow[t]{2}{*}{ findings type } & \multirow{2}{*}{$\begin{array}{c}\text { number } \\
\text { of } \\
\text { findings }\end{array}$} & \multirow{2}{*}{$\begin{array}{c}\text { number of } \\
\text { recommen } \\
\text { dations }\end{array}$} & \multicolumn{4}{|c|}{ Status TLHP } \\
\hline & & & & $\begin{array}{c}\text { already } \\
\text { actiona } \\
\text { ble }\end{array}$ & $\begin{array}{c}\text { in the } \\
\text { process of } \\
\text { completio } \\
\mathrm{n}\end{array}$ & $\begin{array}{l}\text { yet in } \\
\text { follow- } \\
\text { up }\end{array}$ & $\begin{array}{c}\text { not } \\
\text { actionabl } \\
\mathrm{e}\end{array}$ \\
\hline 01 & $\begin{array}{l}\text { Findings of the losses to the state / } \\
\text { region }\end{array}$ & 11 & 12 & 5 & 7 & 0 & 0 \\
\hline 02 & Findings of the tax / levy unpaid & 23 & 20 & 12 & 10 & 0 & 0 \\
\hline
\end{tabular}




\begin{tabular}{|c|l|c|c|c|c|c|c|}
\hline 03 & $\begin{array}{l}\text { The findings of the administrative } \\
\text { problems }\end{array}$ & 418 & 473 & 344 & 123 & 4 & 0 \\
\hline AMOUNT & 452 & 505 & 361 & 140 & 4 & 0 \\
\hline
\end{tabular}

Source:report of the follow-up examination results West Sumbawa Regenc Inspectorate, period January 2016

Based on the completion of the follow-up recapitulation data above, it can be seen in the fact the settlement TLHP who are still in the process and has not been followed up. This study attempted to investigate carefully to make the process of analysis of the compliance Village in the implementation of the completion of actions taken by the subject (people involved) related to the duties and functions performed by each subject / individual (officer on Village) in accordance with the recommendations of the Inspectorate auditors West Sumbawa.

\section{Theoretical Framework And Hypothesis Development}

Compliance theory more emphasis on the importance of socialization processes in affecting an individual compliance behavior as described by Tyler, (in Saleh and Susilowati, 2004), states that there are two perspectives in the sociological literature on compliance with the law, called the instrumental and normative. Instrumental perspective assumes the individual as a whole is driven by self-interest and response to the changes related to the behavior. Normative perspective relate to what counts as moral as opposed to private interests that tend to obey the law as deemed appropriate and consistent with its internal norms, which are considered a must. (Dewi and Pamudji, 2013),

Based on the normative perspective, the theory of compliance can also be applied in the field of supervision carried out against the auditee directed to obtain reasonable assurance of the effectiveness and efficiency of the organization and compliance with the auditee in following procedures, standards, and certain rules laid down by the authorities. TLHP also must promote compliance of the auditee in an effort to completion in accordance with the recommendation.

Ripley \& Franklin, 1986 in(Akib, 2010) introduces two (2) approach in policy implementation, namely, the approach to compliance that seeks to establish a compliance agency or individual as subordinate to the agent or individual as a supervisor in an organization and factual approach which assumes that there are many factors that influence the process of policy implementation which requires implementing policies to more freely make adjustments.

In the context of supervision, the auditee should promote adherence to follow the procedures, standards, and rules in solving the follow-up as recommended by the auditor to obtain reasonable assurance of the effectiveness and efficiency of the organization. Implementation of the completion of the follow-up by the auditee is a form of success in the process of policy implementation. Four important factors as the success criteria implementsi policies by Edward III, 1984 in (Akib, 2010), namely communication, resources, bureaucratic attitude or executive and organizational structure, including work flow bureaucratic procedures.

\section{Research Methods}

This study used a qualitative approach with case study method (case study) and focused on the completion status Village TLHP its not and / or unfinished / legitimate. The research design type is Type 3 (multiple-case design (holistic)) because it uses some of the objects of cases undertaken by several Village using one unit of analysis is the completion TLHP.

The analysis technique used is a thematic analysis of the interview data were obtained from informants yamg as head / head of Village, Secretary and Treasurer expenditure Village.Village in West Sumbawa regency. Thematic analysis by Braun and Clarke(Sofyani, 2015) used for identifying, analyzing, and reporting patterns in the data themes that focus on specific aspects that are most relevant and enabling researchers to engage with theory.

\section{Results}

The research data obtained by categorizing Village who had follow-up status in the process and / or have not been followed up more than two (2) recommendations based on LHPT Monitoring Unit West Sumbawa District Inspectorate for the reporting period in January 2016. Based on the categorizing data obtained in Table 2 as follows :

Table 2: Object Research based on the criteria of more than 2 (two) on the status of the process and has not followed up

\begin{tabular}{|c|c|c|c|c|c|c|c|c|}
\hline \multirow[t]{3}{*}{ No } & \multirow[t]{3}{*}{ Work Unit } & \multicolumn{6}{|c|}{ Progress follow-up status } & \multirow[t]{3}{*}{ number LHP } \\
\hline & & \multicolumn{3}{|c|}{ In the process } & \multicolumn{3}{|c|}{ Yet in Follow-up } & \\
\hline & & 01 & 02 & 03 & 01 & 02 & 03 & \\
\hline 1. & Seteluk Atas Village & & & 4 & & & & $\begin{array}{l}\text { 700-R / } 078 \text { / ITK / } 2015 \\
700-\mathrm{R} / 079 \text { / ITK / } 2015\end{array}$ \\
\hline 2. & Seteluk Bawah Village & & & 3 & & & & 700-R / 080 / ITK / 2015 \\
\hline 3. & Batu Putih Village & 1 & & 2 & & & & 700-R / 081 / ITK / 2015 \\
\hline
\end{tabular}




\begin{tabular}{|r|l|c|c|c|c|c|c|c|}
\hline 4. & Beru Village & & & 3 & & & & $700-\mathrm{R} / 083$ / ITK / 2015 \\
\hline 5. & Belo Village & 1 & & 4 & & & & $700-\mathrm{R} / 103$ / ITK / 2015 \\
\hline 6. & Sapugara Village & & & & & & 3 & $700-\mathrm{R} / 104$ / ITK / 2015 \\
\hline 7. & Kemuning Village & & & 3 & & & & $700-\mathrm{R} / 105$ / ITK / 2015 \\
\hline 8. & Sekongkang Bawah Village & & & 3 & & & & $700-\mathrm{R} / 106$ / ITK / 2015 \\
\hline 9. & Mataiyang Village & 2 & & 2 & & & & $700-\mathrm{R} / 109$ / ITK / 2015 \\
\hline 10. & Rempe Village & & & 6 & & & 1 & $700-\mathrm{R} / 117$ / ITK / 2015 \\
\hline
\end{tabular}

Source $\quad$ : report of the follow-up examination results West Sumbawa Regenc Inspectorate, period January 2016 Description: 01, 02, 0.3 = Findings code in table 1: Table 1: Recapitulation report the results of the monitoring of the follow-up by the monitoring unit of the Inspectorate of West Sumbawa Regency

Implementation of the examination until the completion TLHP is a series of regulatory process in accordance with Regulation of the Minister of State for Administrative Reform No. 9 of 2009 which states "Supervision as a process is a series of uninterrupted supervision from the planning stage to the finished actionable surveillance results". West Sumbawa District Inspectorate also conducts monitoring of the completion TLHP by Village in order to guarantee the implementation of the settlement TLHP accordance with the recommendations of the auditors.

Researchers conducted the interpretation of research results conducted by the settlement TLHP Village in West Sumbawa regency to pair it with theories, concepts, applicable regulations and the results of previous studies that have relevance to the course of this study. Researchers have carried out cluster into four (4) themes based on the criteria of success in the implementation of policies concerning the completion of follow-up to the recommendations of the Inspectorate auditor in the Audit Reports conducted by Village in West Sumbawa.

\section{Theme 1: Communication}

West Sumbawa District Inspectorate as APIPs carry out inspections resulted in findings of administrative or financial findings are compiled in LHP based on Standard Operating Procedure (SOP) to assess the performance of Village in particular in the form of regular inspections(Inspectorate West Sumbawa Regency, 2015),

LHP is used as a medium of communication in order to provide guidance for Village. To further ensure compliance in implementing the settlement TLHP by Village according to the rules of the Minister of State for Administrative Reform No. 9 of 2009, monitoring by APIPs implemented by way of oral communication (meeting mechanism or visits) and written communication (reporting mechanism / strikes) with officials responsible for carrying out the follow-up.

Inspectorate auditor's examination of West Sumbawa overall has benefited the performance of Village. The informant stated that the evaluation of the performance / activity Village is a form of the perceived benefits of the inspection carried out in order to measure the extent to which performance of the Village that have been implemented so as to find out the weaknesses of the management, the financial side and the other side. These results are consistent with the results of research that has been done by(Prihartono, 2009) which states that the follow up of audit findings have a big hand in the implementation of good governance practices and free from corruption, collusion and nepotism.

Completion TLHP by Village only be carried out properly if the communication media are presented in a clear, complete, accurate, objective and easy to understand. Communication has been built in the form of LHP auditor, may be useful by Village, when the official responsible is committed to carry out the completion of the auditor TLHP West Sumbawa District Inspectorate so as to assist in the improvement according to the recommendations.

Successful resolution of these TLHP indicate that communication has been established with either the examiner with the checked and between superiors and subordinates in the Village or management. Completion TLHP by Village in West Sumbawa regency is as a form of compliance in appropriate policy implies Minister of State for Administrative Reform No. 9 of 2009 so Village in West Sumbawa regency could benefit from an examination conducted by the auditor.

\section{Theme 2: Resource}

The challenge to realize the implementation of good governance practices and free from corruption, collusion and nepotism, demanding sectors in the West Sumbawa regency to allocate its resources effectively and efficiently implement the program / activity. Components of the resource includes the number of employees, the expertise of the employees, the information is relevant and sufficient to implement policies and compliance related resources in the implementation of the program, the authority which ensures that the program can achieve the goals yamg expected, as well as their supporting facilities that can be used to perform activities such as funding programs and infrastructure.

Assessment of the effectiveness and efficiency of the resources used Village to do with internal oversight through inspection by the auditors of the Inspectorate. In order to achieve optimal supervision, then any APIPs 
supervision findings must be followed up by Village consistently emphasizes the responsibility of the head / leader in the development of employees. Failure to carry out the settlement TLHP by Village, for whatever reason can be considered as a form of extravagance in the use of financial resources and human resources areas.

The difficulty for human resources is also common in Village because of that it is difficult once an employee wants to be appointed as the treasurer of the employee even accounting background or when one of these employees have started understanding on financial management and accounting (Tarigan \& Nurtanzila, 2013), The difficulty in line with the results of interviews in this study lead to human resource issues are often the cause of the findings in the examination.

Results of interviews with informants concluded that the cause of the inspection findings West Sumbawa District Inspectorate auditor because of limitations in the administration department of the supporting instruments and the bureaucracy that is the limited number and capacity in terms of administrative and financial management. Results were also consistent amid the results of research that has been done by(Suryanto, 2016) who stated that the cause of their findings at the time of the examination is of the internal factors, namely human resources organizational apparatus of uneven ability in the ranks of government, and human resources leadership in directing, motivating, guiding and coordinating the subordinate is not maximized.

Resource has an important role, contributing to the achievement of objectives Village. Inadequate human resources resulted in the implementation of the program can not be perfect so that success in policy implementation especially TLHP settlement efforts will be difficult to achieve. For that we need good human resources management in the context of the completion of TLHP that the goals of the West Sumbawa Regency Inspectorate inspection can be achieved.

\section{Theme 3: The attitude of the bureaucracy or executor}

Follow-up monitoring reports to be very important because the success or failure of supervision of local government processes can be seen from the level of compliance of local governments to implement the recommendations of the results of government oversight officials (Hasmawali, 2012),

At the unit level, the factors that influence the effectiveness of policy implementation TLHP settlement is the attitude of the implementor. Head / leadership as responsible TLHP settlement with the authority in Village have signed LHP fill the form rekomensai by auditors Inspectorate West Sumbawa, making it mandatory for the implemented solution. The realization of this leadership support is put in place policies a top priority, well completion executive placement, and the provision of sufficient funds in order to make room for the implementers TLHP settlement.

Results of research on Village leadership commitment in West Sumbawa regency, it was concluded that the leadership has made the commitment and completion TLHP as a priority so that it will be able to implement better TLHP dibadingkan settlement with the leadership of the less committed. Village leadership's commitment in the form of coordination with all relevant parties in order to discuss the measures or solutions TLHP settlement.

Results were in line with the results of research conducted by (Arini, 2014) which explains the need for support in terms of commitment, leadership, motivation and communication of managers at all levels the implementation of the follow-up LHP SPI in the form of written policies and all managers need to coordinate the efforts of the implementation of the follow-up, as well as the importance of evaluation and monitoring of the implementation of the follow-up LHP by SPI.

As a form of implementation of the completion TLHP in terms of reporting that has been done by Village, as stated by the informant on the results of this study that the handover documents as proof of completion TLHP, the findings related to the administration and finance-related findings. Special financial findings in the form of return of deposits, the proof of evidence attached Certificate of Deposit (STS). All the evidence TLHP settlement was submitted to the monitoring unit Inspectorate West Sumbawa regency, accompanied by a receipt.

The results of research related to depositing evidence TLHP settlement in line with the results of research by (Hasymi, 2016) which states that the auditee or work units in spending money or receiving money needs to be supported by legal documents and incomplete information on documents in order to improve financial management.

Implementation TLHP settlement before the settlement deadline in accordance with the recommendations of the Inspectorate auditors West Sumbawa Regency is an obligation that must be carried out as a form of obedience Village in the Minister of State for Administrative Reform number 9 in 2009

In efforts to resolve TLHP by Village should be explained also that Village has followed the advice / recommendation of the auditors of the Inspectorate in different ways with advice / recommendations given in LHP, the auditor should perform an assessment of the effectiveness of the completion of the actions taken. Auditors must not impose its recommendations should be able to receive actionable yet another step that turned out to be more effective(Association Of Internal Auditors The Government Of Indonesia (AAIPI), 2013),

\section{Theme 4: The organizational structure and work flow bureaucratic procedures}


Village must involve all components in oganisasi by forming a pattern of relationships in the context of the completion TLHP task, especially against those directly related to the recommendations. The assignment relationship patterns are coordinated by the head / head of Village. The participation of each level / organizations in TLHP settlement will assist and enhance better communication so as to encourage their coordination. The organizational structure has a significant impact on policy implementation in order plaksanaan TLHP settlement.

The implementers as possible policy implementor understand the intent and purpose of the recommendations in the LHP auditors, but often fails in the effort to completion, resulting from bureaucratic work flow system is still not working as it should.

Results of the study were described by informants about the obstacles in implementing the settlement TLHP stated that the obstacles often encountered are the findings related to finance, it usually takes a little longer, especially related to third parties / partners who do not clear the address or has moved,

Failure Village overcome the obstacles in the completion TLHP could affect Village performance assessment in order to implement the compliance TLHP settlement policy implementation. Village can be said to not fully utilize the inspection function as one form of coaching is done by the auditor Inspectorate West Sumbawa through the recommendations in the LHP. The findings in the utilization of examination results by Village on this research, along with research(Hasanah, 2012) which states that the results of the examination conducted by the Inspectorate has not been fully utilized as a feed back (feedback) to improve and enhance the performance of Village.

As for the non-performance penalties associated with the completion of the Inspectorate Auditor TLHP West Sumbawa regency, the informant also explained that the witness can be given is in the form of personnel administrative sanctions which usually corresponds to the Government Regulation No. 53 of 2010 on Discipline of Civil Servants. This is similar to what was described in the Regulation of the Minister of State for Administrative Reform number 9 in 2009 which explained that the unit leader at the government agency that does not perform the obligation to follow the recommendations in the LHP penalized in accordance with the provisions of the legislation in force, namely legislation number 15 of 2004 on State Treasury of article 20, paragraph 5, which states that officials are known to not carry out the obligations referred to in paragraph (1) is an official shall follow the recommendations in the report of examination results, may be subject to administrative sanctions in accordance with the provisions of the legislation in the field of staffing, namely: Government Regulation No. 30 of 1980 on the Civil Servants Disciplinary Regulations which have been converted into Government Regulation No. 53 of 2010 on Civil Service Discipline.

\section{Conclusion, Implication And Limitation}

Limitations of the problem in this study where the research only examines the findings that are not and or have not been completed follow up by the village finance manager, where the Report of the Inspection Result has not been completed up to the time limit specified in accordance with the mandate of Regulation of the State Minister of Administrative Reform Number 9 in 2009. Data of Inspection Result Report based on findings and inspection results from Inspectorate of West Sumbawa Regency in January 2016.

The Follow Up Issue Issues Report is very important to be observed because practically, the management of village finance in the form of good report that sourced from the Allocation of Village Fund and Village Fund is Belief and responsibilities of village financial managers provided by the government and society in accordance with good governance. $\mathrm{T}$

Theoretically, Follow-up Report of Examination Result conducted by village is part of audit process. The immediate results expected from this study should be that the Village Government must comply with regulations issued by the West Sumbawa District Government to avoid recurring LHP findings and will be a bad achievement for the community so that the community does not trust the financial management Village headand village financial manager. For the future, heads of Village who are generally committed to resolution efforts can communicate better and Village must involve all components within the organization by establishing a pattern of task relationships in the context of TLHP settlement. Implementation of policies is a very important step in the public policy process. In the context of supervision, the completion of the settlement is realized through compliance with the completion of the TLHP settlement to become a determinant of success in the supervision of local government by APIP. The conclusions found in this study are the main obstacles to the cause of the findings that are not and or not yet completed is the lack of good communication at Village Management level in West Sumbawa Regency and still lack of competent Human Resources (HR), so that the completion of TLHP by Village Which is under the supervision of the Inspectorate of West Sumbawa Regency as mandated by the Regulation of the State Minister of State Apparatur Empowerment number 9 year 2009 has not been reached maximally with the existence of TLHP which has not and or not acted upon.

\section{References}

[1] Peraturan Menteri Dalam Negeri nomor 23 tahun 2007 tentang Pedoman Tata Cara Pengawasan atas Penyelenggaraan Pemerintah Daerah. 
[2] Peraturan Menteri Dalam Negeri nomor 64 tahun 2007 tentang Pedoman Teknis Organisasi dan Tata Kerja Inspektorat Provinsi dan Kabupaten/Kota.

[3] Peraturan Menteri Pendayagunaan Aparatur Negara nomor 9 tahun 2009 tentang Pedoman Umum Pelaksanaan Pemantauan, Evaluasi, dan Pelaporan Tindak Lanjut Hasil Pengawasan Fungsional.

[4] Peraturan Pemerintah nomor 30 tahun 1980 tentang Peraturan Disiplin Pegawai Negeri Sipil.

[5] Peraturan Pemerintah nomor 53 tahun 2010 tentang Disiplin Pegawai Negeri.

[6] Peraturan Pemerintah Republik Indonesia nomor 60 tahun 2008 tentang Sistem Pengendalian Intern Pemerinah.

[7] Peraturan Pemerintah Republik Indonesia nomor 79 tahun 2005 tentang Pedoman Pembinaan dan Pengawasan Penyelenggaraan Pemerintahan Daerah.

[8] Undang-Undang nomor 15 tahun 2004 tentang Perbendaharaan Negara

\section{ATTACHMENT}

The model viewer of completion of follow-up in accordance with defined themes:

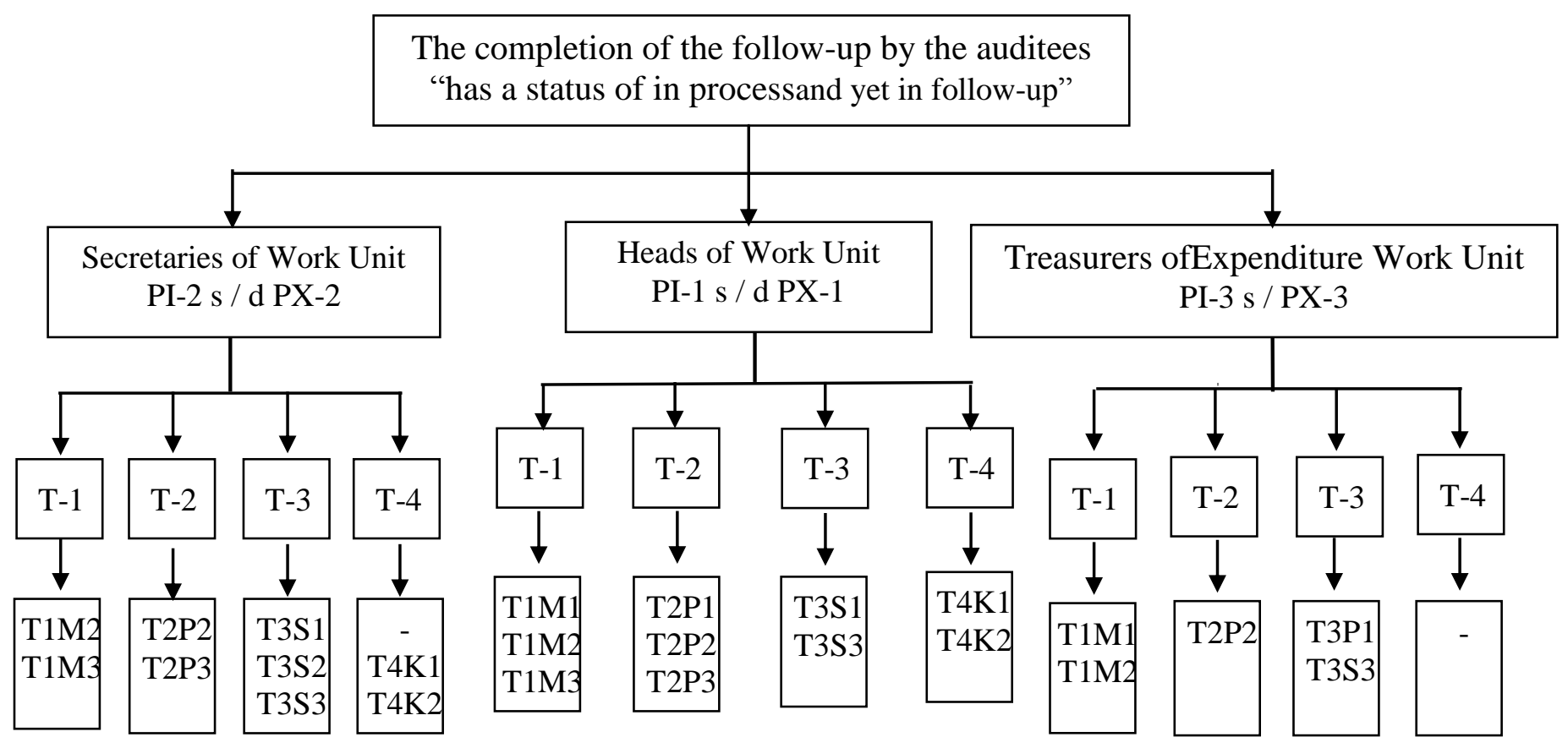

\section{Information:}

PI-1 s / d PX-1 = Informant as Headsof Work Unit

PI-2 s / d PX-2 = Informant as Secretaries ofWork Unit

PI-3 s / PX-3 = Informant as Treasurers of Expenditure Work Unit

$\mathrm{T}-1 \quad=$ Communications

$\mathrm{T}-2 \quad=$ Resources

T-3 = The attitude of the bureaucracy or executor

T-4 = The organizational structure and procedures of bureaucratic flow

T1M1 = Evaluation of internal control system

T1M2 = Evaluation of the program/activity

T1M3 = Assist management

$\mathrm{T} 2 \mathrm{P} 1=$ Limitations of facilities and infrastructure

T2P2 = Limitations of Human Reasource

$\mathrm{T} 2 \mathrm{P} 3$

T3S1

= Weakness immediate supervisor (in the scrutiny attached to)

T3S2

$=$ Commitment leader/supervisor

$=$ Development of Human Resources

T3S3

$=$ Reporting of follow-upTL (proof of completion of follow-up) 
T4K1 = Billing loss of area

T4K2 = Sanctions/penalties

$=$ No indicators 